\title{
Assessing the asymmetric linkages between foreign direct investments and indigenous innovation in developing countries: A non-linear panel auto-regressive distributed lag approach
}

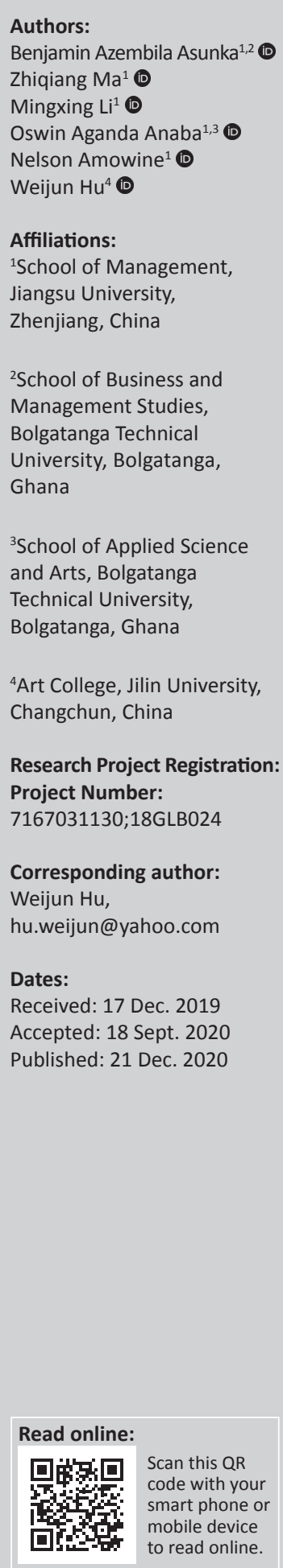

Background: The contributions of indigenous innovation and foreign direct investments (FDI) inflows are critical elements of economic growth and hence very important for developing economies. FDI inflows have been recognised as having a direct influence on innovation in host countries. The relationship between these two variables is explored and well documented in literature. However, these studies have focused on linear relationships between FDI and indigenous innovation, ignoring a possible asymmetric relationship between them.

Aim: The current study aims to analyse the existence of hidden cointegration and asymmetries between the two variables using a non-linear approach.

Setting: The focus of this study is on developing countries. Five countries are selected from the regions of Africa, Asia, Europe and South America. These countries are chosen on the basis of economic status (all countries are developing countries) and data availability.

Methods: The study employs panel data of 20 developing countries from 1993 to 2017. The study employs the non-linear auto-regressive distributed lag model to test for an asymmetric relationship between the variables. The variables are deconstructed into their negative and positive components to identify possible hidden cointegration and asymmetries that exist between them. This method allows for the detection of long-run asymmetric relationships in a non-linear fashion.

Results: The empirical findings show that a long-run cointegration and asymmetric relationship exists between the negative and positive components of FDI and indigenous innovation. For the four regions, positive changes in FDI directly influence positive changes in indigenous innovation. Negative changes in FDI have no effect on the positive changes in indigenous innovation in the countries under study. However, negative changes in FDI influence negative changes in indigenous innovation across the four regions.

Conclusion: FDI inflows have a positive and significant effect on indigenous innovation in developing countries, and reduction in FDI can lead to reduction in innovation output in the long term. Policy directions in developing countries will be effective if they are centred on non-linear relationships between the investigated variables.

Keywords: indigenous innovation; FDI; asymmetric cointegration; non-linear panel autoregressive distributed lag model; developing countries.

\section{Introduction}

Indigenous innovation, which involves innovation by the domestic firms of a country, is continually advocated as a main driver of the economic growth of developing economies. This phenomenon promotes technological innovation which is identified as a key component of industrialisation (Intarakumnerd \& Goto 2018; Rodrigues \& Da Costa 2018). Industrialisation driven by indigenous innovation is a major determinant of sustainable economic growth in developing countries. Studies on the effect of foreign direct investments (FDI) on innovation were pioneered by Caves (1974), and since then several scholars have reported that FDI facilitates innovation in developing countries (Awate, Larsen \& Mudambi 2015; Howell 2019; Maurer 2017;

How to cite this article: Asunka, B.A., Ma, Z., Li, M., Anaba, O.A., Amowine, N. \& Hu, W., 2020, 'Assessing the asymmetric linkages between foreign direct investments and indigenous innovation in developing countries: A non-linear panel auto-regressive distributed lag approach', South African Journal of Economic and Management Sciences 23(1), a3496. https://doi.org/10.4102/sajems.v23i1.3496 Copyright: @ 2020. The Authors. Licensee: AOSIS. This work is licensed under the Creative Commons Attribution License. 
Qin \& Du 2017; Shamsub 2014; Tan \& Mathews 2015). One limitation of those studies is that they measure the relationship between FDI and indigenous innovation using linear methods, ignoring the hidden cointegration and asymmetric relationships that may exist between the variables. In an attempt to fill this gap, there is the need to investigate the non-linearities between the two variables, which is the main issue addressed in this study.

Trade openness is a factor that encourages FDI in many economies (Kumari \& Sharma 2017) and technology transfer that comes with FDI benefits developing countries. FDI is an investment involving a long-term relationship in which a foreign entity (foreign direct investor) has a lasting interest and control of an enterprise resident in a country (foreign affiliate) other than that of the foreign direct investor (UNCTAD 2007). Two key words are at play in this definition: lasting interest and control. FDI comes in the forms of private capital and portfolio equity investment. Private capital implies investments with long-term prospects, while portfolio equity investment is done mainly in the short term. The concept of control occurs when the foreign investor has a minimum of $10 \%$ shareholding in a foreign affiliate. According to Moosa (2002), FDI comes in three main forms: (1) the greenfield which is an investment made 'from scratch', to create a completely new enterprise. This type of investment helps in creating jobs and, hence, knowledge spillovers. (2) Joint ventures are investments made by a foreign entity in conjunction with a domestic entity or public institutions. This form of FDI brings expertise with technical and financial skills that can benefit local enterprises in the long term. (3) Mergers and acquisitions involve a change of ownership of the existing enterprise. This involves buying, selling and combining enterprises to form new businesses.

The theoretical bases of knowledge spillovers and other benefits of FDI to domestic businesses are founded in the works of several scholars including those of Ohlin (1952) and Hymer (1976). Hymer argued that FDI activities came about as a result of the existence of imperfect market conditions in different countries which facilitated international trade among countries. This argument is based on the concept of factor proportions which distinguishes between factor endowment structures and trade arrangements. These concepts focus on how trade impacts on the income levels of residents in the countries involved. Ohlin posited that FDI is promoted where a capital-abundant country exports capitalintensive goods, while a country that abounds in labour will export labour goods. This implies that countries that are less endowed in some resources stand to benefit from foreign investors from countries where such resources abound. These perspectives mean investors will be looking at increasing profitability opportunities, hence investing in countries where they can have access to cheaper capital resources. Hymer further stated that foreign investors can be successful if they can compete effectively with domestic companies. The second condition is that the market must be an imperfect one. Razin and Sadka (2012) argued that foreign investors are motivated to invest in projects where they have comparative intangible skills. With superior managerial skills, foreign investors can occupy top levels of management where their specialised skills are required. These ideas mean that developing economies can benefit from technologies and technical skills that are lacking in the domestic market. From knowledge spillovers and technologies that come with foreign investors, domestic businesses in these economies can generate knowledge that will lead to the production of novel technologies to solve domestic problems and those in foreign countries.

Kastrati et al. (2016), among other scholars, have made strong arguments that FDI has a positive effect on indigenous innovation. Zhao et al. (2019) opined that multinational enterprises (MNEs) transfer technical knowhow to their host markets by offering training to local employees who then absorb and leverage knowledge to spur innovation in domestic firms that they later get involved in. With this notion, several developing countries have sought to attract more FDI inflows by offering incentives to foreign investors in a bid to attract them into the local market. These incentives vary from tax to non-tax benefits offered to MNEs to invest in the host market. Knowledge spillovers from MNEs benefit local firms in the medium to long term in their innovation efforts. MNEs bring with them vertical technology spillovers between local and foreign suppliers that seek to serve the same customers through direct and indirect imports.

Moreover, many researchers have found a significant and positive effect of FDI on indigenous innovation efforts by developing countries. Fu and Gong (2011) opined that FDI has been a bedrock for the diffusion of foreign technology from technologically advanced countries into less developed countries. Hence, imports into developing countries associated with FDI activities create 'escape competition' that leads to indigenous innovation (Seenaiah \& Rath 2018; Shu \& Steinwender 2019; Xie \& Li 2018). Medina (2017) posited that import competition could bring about product upgrading opportunities, and local firms will react to changing preference by leveraging existing factors to produce new products (Bloom, Draca \& Van Reenen 2016). Studies show that in the aftermath of trade liberalisation, innovation efforts have been on the increase with foreign goods flooding local markets. This is evident in most studies done in Latin America (Fernandes \& Paunov 2013; Iacovone 2012; Iacovone, Keller \& Rauch 2011).

In contrast, some studies found that FDI suppresses indigenous innovation in developing countries. These negative findings were reported by Aitken and Harrison (1999) for Venezuela, Hu and Jefferson (2002) for China and Barasa et al. (2019) for sub-Saharan Africa. The OECD (2002) reported that domestic firms' innovation efforts in developing countries may be reduced by competition from foreign subsidiaries. Moreover, multinational firms might not open up for local firms to benefit from the technical know-how 
they possess due to lack of effective links with local firms (Seenaiah \& Rath 2018). Tian (2007) argued that foreign firms jeopardise the growth of indigenous innovation due to market-stealing and skill-stealing effects. It has also been argued strongly that developing countries are unable to diffuse new technologies due to lack of skilled human resources (Fu, Pietrobelli \& Soete 2011). Acemoglu (2002) opined that this negative impact could stem from the fact that foreign technologies largely come from developed countries while domestic businesses lack the capacity to utilise these novel technologies.

The above literature shows that findings on the relationship between FDI and innovation have been mixed, leaving the question of asymmetries between the variables unanswered. The aim of this study, therefore, is to bring to the fore the asymmetric linkages between FDI and indigenous innovation in developing economies around the world. This study goes beyond the linear relationship between the two variables by digging out how increasing and decreasing FDI inflows influence innovation output registered by residents of the countries studied.

Studying asymmetric relationship is essential to finding any cointegration that may be hidden in some components of the variables. The development of this methodology is spurred on by the fact that linear models are restrictive and therefore unable to reveal such hidden relationships. Based on this, Shin, Yu and Greenwood-Nimmo (2014) proposed a bivariate asymmetric cointegration model in which the variables are decomposed into their negative and positive components. Their non-linear dynamic model simultaneously models asymmetries and the underlying long-run relationships in the variables. The model further derives an error correction term associated with the asymmetric cointegration regression, producing the non-linear autoregressive distributed lag (ARDL) model. The relationship between these decomposed components is tested wherever the variables are found not to be cointegrated in a linear form. Non-linear methods have been applied in several contexts to study relationships between variables, including energy and economic growth (Araç \& Hasanov 2014; Bayramoglu \& Yildirim 2017; Kouton 2019; Ndoricimpa 2017), economic production (Burke, Hsiang \& Miguel 2015), corporate social responsibility and financial performance (Nollet, Filis \& Mitrokostas 2016), oil prices and implied volatilities (Lin, Liang \& Tsai 2019), credit ratings announcements and financial market development (Li et al. 2019). Hence, this study finds the non-linear ARDL an appropriate model to test the asymmetric relationships between FDI and indigenous innovation.

Interestingly, previous studies have focused mainly on the linear relationship between the two variables leaving a vacuum in the potential non-linear relationship that may exist between them. The current study contributes to literature in this area by addressing two main issues: firstly, it tests for hidden cointegration between the two variables to reveal any long-run cointegration between their negative and positive components. Secondly, it tests for asymmetric relationships between the variables by analysing the effect of increasing and decreasing levels of FDI on the variations in indigenous innovation.

The study is further organised in the following order: an explanation of the methodological approach adopted, results and conclusions.

\section{Materials and methods}

To achieve the objective of this study, we use the non-linear panel ARDL model to analyse the possible asymmetric relationship between FDI and indigenous innovation. To analyse this model effectively, we first analyse the stationarity of the data using the Pesaran (2007) cross-sectional IPS (CIPS) test for the unit root which takes into account cross-sectional dependence (CD) in the data. Further, a test for both symmetric and asymmetric cointegration is carried out on the variables, and finally the non-linear panel ARDL is estimated for whole panel and separately for each continent.

\section{Data}

Data for this study are taken from the World Development Indicators by the World Bank group (www.data.worldbank. org/indicator). The data cover 20 countries across the regions of Africa, Asia, South America and Europe for the period between 1993 and 2017. Five countries are taken from each region. These countries are chosen on the basis of economic status (all countries are developing countries). The sampled countries are all middle-income countries (both upper and lower middle income). The sample includes five countries from Africa (Egypt, Morocco, Algeria, Tunisia and South Africa), five countries from Asia (China, India, Pakistan, Philippines and Sri Lanka), five countries from Europe (Bulgaria, Russia, Slovenia, Ukraine and Moldova) and five countries from South America (Brazil, Argentina, Columbia, Ecuador and Peru). The reasons for capturing both upper and lower middle-income countries is data availability. Data on patents registered by residents of developing countries are very scant, hence a major constraint. Secondly, the study sought to include countries that are performing very well in innovation in their respective regions following classifications by Cornell University, INSEAD (2019).

\section{Study variables}

The two main variables used in this study are indigenous innovation and FDI inflows. Indigenous innovation is made up of the number of patents and trademarks registered by the residents of each country under study. Following several other studies, patents and trademarks are used as a proxy for innovation, and those registered by the residents of a country are used in this study for indigenous innovation. Patents have been largely used as a proxy for innovation in extant literature (Burhan, Singh \& Jain 2017; Clancy et al., 2020; Crosby 2000; Lv, Qi \& Dong 2020). Trademark 
applications are also increasingly being used as a proxy for product and service innovations in extant literature (Block et al. 2014; Gotsch \& Hipp 2012; Schautschick \& Greenhalgh 2016; Yoshioka-Kobayashi, Miyanoshita \& Kanama 2020). A summary description of the variables and data is captured in Table 1. From the descriptive statistics, it can be observed that the combined investments in FDI, as well as indigenous innovation by Asian countries are the largest. African countries registered the least amount of FDI inflows and the lowest maximum number of innovations for the period under study, perhaps an indication that FDI inflows do have a positive influence on the innovation efforts of indigenous firms in developing countries. However, selected countries for Europe and South America registered almost the same amount of FDI inflows, but the number of innovations churned out by South American countries is higher than that of Europe. These dynamics further demonstrate that there could be asymmetries between the two variables that a simple linear analysis will not capture.

\section{Unit root analysis}

A check for stationarity of the data is done by conducting a unit root analysis. The rationale for testing data for stationarity is to be sure that there is no form of shock that would throw the series out of its long-term equilibrium. To achieve this, the CIPS test (Pesaran 2007) is used. This method is particularly suited for a study of this nature with heterogeneous panels since it accounts for CD effect within the data. The null hypothesis of this test is the presence of a unit root against the alternative of a stationary series.

The CIPS test is based on the following formula:

$\Delta y_{i t}=\alpha_{i}+b_{i} y_{i t-1}+\gamma_{i} f_{\mathrm{i}}+\varepsilon_{i t}$

$i=1,2, \ldots, N . t=1,2, \ldots, T$

[Eqn 1]

TABLE 1: Summary statistics of data

\begin{tabular}{lccccc}
\hline Variable & Observations & Mean & $\begin{array}{l}\text { Standard } \\
\text { deviation }\end{array}$ & Minimum & Maximum \\
\hline Total & 500 & 105520 & 324102 & 232 & 3143890 \\
Innovation & 500 & 14333 & 36483 & 2 & 290928 \\
FDI & 125 & 6535 & 6052 & 545 & 23438 \\
Africa & 125 & 2194 & 2482 & 2 & 11578 \\
Innovation & 125 & 237998 & 618002 & 1642 & 3143890 \\
FDI & 125 & 29557 & 63084 & 55 & 290928 \\
Asia & 125 & 14971 & 20121 & 232 & 69379 \\
Innovation & 125 & 13536 & 23402 & 11 & 102427 \\
FDI & & & & & \\
Europe & 125 & 35424 & 37161 & 2934 & 164672 \\
Innovation & 125 & 12044 & 20142 & 165 & 102427 \\
FDI & & & & & \\
South America & & & & & \\
Innovation & 125 & & & & \\
FDI & 125 & & & & \\
\hline
\end{tabular}

Note: Figures for FDI are in millions of dollars while those for innovation are number of units. $\mathrm{FDI}$, foreign direct investments.
$\Delta y_{i t}=y_{i t}-y_{i t-1} ; y_{i t}$ is an $i^{\text {th }}$ item observed at time $t, \alpha_{i}$ is the intercept and $b_{i}$ is the parameter of $y_{i t-1} \cdot \gamma_{i} f_{i}$ represents the CD element where $\gamma_{i}$ is a factor that is common to all crosssectional units $i$, and $f_{i}$ is the latent factor, while $\varepsilon_{i t}$ is the error term. Negative values for $b_{i}$ are to be expected where there is an absence of the unit root. The test hypothesis is defined as:

$\mathbf{H}_{0}: b_{i}=0 ; \forall i=1,2, \ldots, N$

$\mathbf{H}_{1}: b_{i}<0 ; \forall i=1,2, \ldots, N$

The outcome of the unit root test will give a clue as to whether the relationship between indigenous innovation and FDI is temporary or permanent. If the variables are stationary, then FDI can be said to have a transitory effect on indigenous innovation, wherever the variables return to their long-term equilibrium after any shock. In the presence of a unit root, there will be indication of a permanent effect between the variables. However, in the presence of a unit root and a subsequent cointegration between the variables, then the effect will be temporary; if there is no cointegration in this case, then any effect will be permanent.

\section{Cointegration analysis}

Prior to testing for causal relationships between the variables, it is important to first test for cointegration between them in order to determine the nature of the relationship that exists. This study begins the cointegration analysis by first testing for linear cointegration, and proceeds to test non-linear cointegration. The latter test demands that the variables be decomposed into their positive and negative elements for an effective test of non-linear cointegration. Like the unit root test, $\mathrm{CD}$ in the variables needs to be considered in the test for cointegration, hence the panel cointegration test by Westerlund (2007) is adopted for this purpose. This test produces four test statistic results of possible cointegration between the variables. Firstly, there are the $G a$ and $G t$ tests which test for cointegration in at least one cross-sectional unit based on the null hypothesis of no cointegration. A rejection of this null hypothesis, therefore, means cointegration exists in at least one of the cross-sections. Secondly, there are the $P t$ and $P a$ tests which test for cointegration for the panel as a whole; the null hypothesis is no cointegration, and a rejection of this hypothesis shows there is cointegration between the variables in the whole panel. The CD element is computed using bootstrap replications to produce robust $p$-values for assessing the null hypothesis.

The next step in the test for cointegration is to test for asymmetric cointegration between the panels. This test is conducted on the negative and positive components of the variables to test for the any hidden links between them. Hence, this test is referred to as hidden panel cointegration, because it assumes that no cointegration exists between the variables themselves but between their hidden properties. These hidden dynamics would not be obvious in a linear test but do exist in an asymmetric manner. Asymmetric cointegration is tested 
when the series are integrated at order one. Hatemi-J (2014) proposes that the variables $\mathrm{Y}$ and $\mathrm{X}$ can be decomposed into their positive and negative components as follows:

$y_{i t}^{+}=\sum_{k=1}^{\mathrm{t}} \Delta y_{i k}^{+}=\sum_{k=1}^{t} \max \left(\Delta y_{i k}, 0\right)$

$y_{i t}^{-}=\sum_{k=1}^{t} \Delta y_{i k}^{-}=\sum_{k=1}^{t} \min \left(\Delta y_{i k}, 0\right)$

[Eqn 3]

$x_{i t}^{+}=\sum_{k=1}^{t} \Delta x_{i k}^{+}=\sum_{k=1}^{t} \max \left(\Delta x_{i k}, 0\right)$

[Eqn 4]

$x_{i t}^{-}=\sum_{k=1}^{t} \Delta x_{i k}^{-}=\sum_{k=1}^{t} \min \left(\Delta x_{i k}, 0\right)$

[Eqn 5]

Following Hatemi-J (2020), the cointegration equations can be written as:

$y_{i t}^{+}=\alpha_{\mathrm{i}}^{+}+\beta_{i}^{+} x_{i t}^{+}+\varepsilon_{i t}^{+}$

[Eqn 6]

$y_{i t}^{-}=\alpha_{i}^{-}+\beta_{i}^{-} x_{i t}^{-}+\varepsilon_{i t}^{-}$

[Eqn 7]

The positive and negative cumulative shocks are integrated if the residuals $\varepsilon_{i t}^{+}$and $\varepsilon_{i t}^{-}$are stationary.

\section{Non-linear panel auto-regressive distributed lag}

Numerous studies have used the ARDL model to test relationships among various variables. Common among them is the test of the relationship between FDI and other economic variables in various settings. The non-linear ARDL which was proposed by Shin et al. (2014) has also gained popularity in extant literature that tests the relationship between various macroeconomic variables. This method allows for the detection of long-run asymmetric relationships in a non-linear fashion. The test allows for decomposition of the dependent variable into its negative and positive components, while the variable is simultaneously tested in the same equation in its normal form. This test of dynamic panels has been found to also be appropriate for large $\mathrm{T}$ panel data modeling (Salisu \& Isah 2017).

The following equation is specified to test the asymmetric relationship between the two variables (Kouton 2019).

$$
\begin{aligned}
\Delta y_{i t}= & \alpha_{0}+\alpha_{1} y_{i t-1}+\alpha_{2}^{+} x_{i t}^{+}+\alpha_{2}^{-} x_{i t-1}^{-}+\sum_{\mathrm{k}=1}^{\mathrm{p}} \gamma_{k} \Delta y_{i t-k}+ \\
& \sum_{k=0}^{q}\left(\delta_{k}^{+} \Delta x_{i t-k}^{+}+\delta_{k}^{-} \Delta x_{i t-k}^{-}\right)+\mu_{i}+\varepsilon_{i t}
\end{aligned}
$$

$\mathrm{Y}$ is the dependent variable (indigenous innovation) and $\mathrm{X}$ is the independent variable (FDI). Both variables are estimated in their logarithm form: $\mu_{i}$ and $\varepsilon_{i t}$ represent the countryspecific effect and error term, while the lags of the variables are represented by the notations $p$ and $q$. The long-run asymmetries are captured by $\alpha_{2}^{+}$and $\alpha_{2}^{-}$while the short-run asymmetries are captured by $\delta_{k}^{+}$and $\delta_{k}^{-}$.

The asymmetric relationship is then tested by separating the impact of positive shocks from negative shocks (Hatemi-J 2020; Kouton 2019). Hence the non-linear panel ARDL model is specified as follows:

$$
\begin{aligned}
\Delta y_{i t}^{+}= & \alpha_{0 \mathrm{i}}+\alpha_{1 i}^{+} y_{i t-1}^{+}+\beta_{1 j}^{+} x_{i t-1}^{+}+\sum_{j=1}^{p} \gamma_{i j}^{+} \Delta y_{i t-j}^{+}+ \\
& \sum_{j=0}^{q} \delta_{i j}^{+} \Delta x_{i t-j}^{+}+\mu_{i}+\varepsilon_{i t} \\
\Delta y_{i t}^{+}= & \alpha_{0 \mathrm{i}}+\alpha_{2 i}^{+} y_{i t-1}^{+}+\beta_{2 j}^{-} x_{i t-1}^{-}+\sum_{j=1}^{p} \gamma_{i j}^{+} \Delta y_{i t-j}^{+}+ \\
& \sum_{j=0}^{q} \delta_{i j}^{-} \Delta x_{i t-j}^{-}+\mu_{i}+\varepsilon_{i t} \\
\Delta y_{i t}^{-}= & \alpha_{0 \mathrm{i}}+\alpha_{1 i}^{-} y_{i t-1}^{-}+\beta_{2 j}^{-} x_{i t-1}^{-}+\sum_{j=1}^{p} \gamma_{i j}^{-} \Delta y_{i t-j}^{-}+ \\
& \sum_{j=0}^{q} \delta_{i j}^{-} \Delta x_{i t-j}^{-}+\mu_{i}+\varepsilon_{i t} \\
\Delta y_{i t}^{-}= & \alpha_{0 \mathrm{i}}+\alpha_{1 i}^{-} y_{i t-1}^{-}+\beta_{2 j}^{+} x_{i t-1}^{+}+\sum_{j=1}^{p} \gamma_{i j}^{-} \Delta y_{i t-j}^{-}+ \\
& \sum_{j=0}^{q} \delta_{i j}^{+} \Delta x_{i t-j}^{+}+\mu_{i}+\varepsilon_{i t}
\end{aligned}
$$

$\Delta y^{+}$and $\Delta y$ represent the increasing and decreasing amounts of indigenous innovation, while $\Delta x^{+}$and $\Delta x$ represent the increasing and decreasing amounts of FDI.

If the negative and positive components of the variables are found to be cointegrated, then an error correction representation is estimated as follows:

$$
\Delta y_{i t}^{+}=\alpha_{0 i}+\pi_{1 i}^{+} \xi_{i t-1}^{+}+\sum_{j=1}^{p} \gamma_{i j}^{+} \Delta y_{i t-j}^{+}+\sum_{j=0}^{q} \delta_{i j}^{+} \Delta x_{i t-j}^{+}+\mu_{i}+\varepsilon_{i t}
$$

[Eqn 13]

$$
\Delta y_{i t}^{+}=\alpha_{0 i}+\pi_{2 i}^{-} \xi_{i t-1}^{-}+\sum_{j=1}^{p} \gamma_{i j}^{-} \Delta y_{i t-j}^{-}+\sum_{j=0}^{q} \delta_{i j}^{-} \Delta x_{i t-j}^{-}+\mu_{i}+\varepsilon_{i t}
$$

$$
\Delta y_{i t}^{-}=\alpha_{0 i}+\pi_{1 i}^{-} \xi_{i t-1}^{-}+\sum_{j=1}^{p} \gamma_{i j}^{-} \Delta y_{i t-j}^{-}+\sum_{j=0}^{q} \delta_{i j}^{-} \Delta x_{i t-j}^{-}+\mu_{i}+\varepsilon_{i t}
$$

$$
\Delta y_{i t}^{-}=\alpha_{0 i}+\pi_{2 i}^{+} \xi_{i t-1}^{+}+\sum_{j=1}^{p} \gamma_{i j}^{+} \Delta y_{i t-j}^{+}+\sum_{j=0}^{q} \delta_{i j}^{+} \Delta x_{i t-j}^{+}+\mu_{i}+\varepsilon_{i t}
$$

$\xi_{i t-1}$ is the error-correction term that captures the long-run equilibrium in the model, while $\pi_{i}$ is the speed of adjustment time at which the system returns to equilibrium after a shock.

After determining that the cointegration exists in the positive and negative components of the variables, it is appropriate to estimate the relationship using the non-linear panel ARDL. The error correction term is estimated alongside this cointegration analysis. To achieve this, the study employs the pooled mean group (PMG) or mean group (MG) estimators to estimate the equations. The advantage of these estimators over other econometric tools is that we are able to estimate both short-run and long-run dynamics. In order to determine the efficient estimator between the PMG and the MG, the Hausman test is conducted after estimating each equation. The null hypothesis of this test is that there is no vast difference between the two estimators, hence the PMG is the efficient estimator. Therefore, a rejection of the null hypothesis will mean that the MG is the efficient estimator and PMG and MG are effective tools for estimating 
relationships in heterogeneous panels (Kouton 2019). The difference in the two estimators lies in how they treat the pooling coefficients. The PMG combines pooling and averaging coefficients in estimating the relationship. The MG on the other hand handles only the averaging coefficients.

\section{Testing for asymmetric panel causality}

Firstly, the study checks for causality in a linear framework by conducting the panel causality test using the test proposed by Dumitrescu and Hurlin (2012). The advantage of this test over time-series tests is that it considers both possible heterogeneity and CD. The null hypothesis of this test is that there is no causality from the independent variable to the dependent variable for all the cross-units in the panel. A rejection of the null hypothesis means there exists causality of the independent variable to the dependent variable. Secondly, it goes on to test for panel causality test using the asymmetric causality by Hatemi-J (2011). The asymmetric causality test is conducted by first decomposing the variables into their positive and negative components. Following this, a panel causality test is conducted using a vector autoregressive model as follows:

$$
\begin{array}{lcllll}
x_{i t}^{+} & \alpha_{i 0} & \sum_{j=1}^{p} \alpha_{i 1 j} & \sum_{j=1}^{p} \alpha_{i 2 j} & x_{i t-j}^{+} & \varepsilon_{i 2}^{+} \\
y_{i t}^{+}= & \beta_{i 0}+\sum_{j=1}^{p} \beta_{i 1 j} & \sum_{j=1}^{\mathrm{p}} \beta_{i 2 j} & \times y_{i t-j}^{+}+\varepsilon_{i 2}^{+}
\end{array}
$$

The asymmetric causality is tested using the Wald test. The test is conducted by pairing the positive and negative components of the variables.

\section{Ethical consideration}

This article followed all ethical standards for carrying out research without direct contact with human or animal subjects.

\section{Results}

\section{Test for unit root}

For a study that deals with large panels, it is necessary to test for $\mathrm{CD}$ before proceeding to do the unit root analysis. A CD test is necessary to determine if variations in the variables of one country affect those of another country under study, particularly because there are similarities among these countries. This test is done based on the Pesaran CD test; the null hypothesis is cross-sectional independence against the alternative of CD. Results of the CD test in Table 2 show a rejection of the null hypothesis for both variables, confirming the presence of $C D$. The results of $C D$ in both variables could be due to globalisation and international trade which make it easy for a shock in one economy to affect other economies as well (Nazlioglu 2011). The presence of CD in the variables is good grounds for the use of the CIPS test by Pesaran (2007). The test is conducted at three levels: firstly the model is tested with a constant, secondly without a constant or trend, and thirdly with a constant and trend. The results of the CIPS unit root test as shown in Table 2 indicate stationarity of the variables at first difference on all three lags selected.

\section{Cointegration analysis}

Since the data is proven to be stationary at order 1 , we proceed to estimate the cointegration between the variables. In this analysis the Westerlund (2007) panel cointegration test is used since it takes into consideration the cross-sectional effect in the data which has been established in this study. The robust $p$-values are generated using 300 bootstrap replications. The results of the cointegration test as captured in Table 3 show an acceptance of the null hypothesis of no cointegration between the variables. This outcome gives the grounds for the decomposition of the variables into their

\begin{tabular}{|c|c|c|c|c|c|c|c|c|c|c|c|}
\hline \multirow[t]{2}{*}{ Variables } & \multicolumn{2}{|c|}{$\begin{array}{l}\text { Cross-sectional } \\
\text { dependence test }\end{array}$} & \multicolumn{4}{|c|}{ At level } & \multicolumn{4}{|c|}{ At first difference } & \multirow[t]{2}{*}{ Stationarity } \\
\hline & Test statistics & $p$ & Lag 1 & Lag 2 & Lag 3 & $\begin{array}{c}\text { Critical } \\
\text { value }(5 \%)\end{array}$ & Lag 1 & Lag 2 & Lag 3 & $\begin{array}{c}\text { Critical } \\
\text { value (5\%) }\end{array}$ & \\
\hline \multicolumn{12}{|c|}{ Model with constant } \\
\hline Innovation & 34.03 & 0.00 & -2.127 & -2.127 & -2.158 & -2.2 & -4.846 & -4.846 & -4.719 & -2.2 & I(1) \\
\hline FDI & 33.90 & 0.00 & -1.577 & -1.703 & -1.577 & -2.2 & -4.990 & -5.111 & -5.111 & -2.2 & I(1) \\
\hline \multicolumn{12}{|c|}{ Model without constant or trend } \\
\hline FDI & - & - & -1.011 & -1.011 & -1.011 & -1.61 & -4.986 & -4.986 & -4.986 & -1.61 & I(1) \\
\hline \multicolumn{12}{|c|}{ Model with constant and trend } \\
\hline Innovation & - & - & -2.326 & -2.326 & -2.326 & -2.72 & -4.873 & -4.873 & -4.873 & -2.72 & I(1) \\
\hline FDI & - & - & -2.126 & -2.126 & -2.126 & -2.72 & -5.131 & -5.131 & -5.131 & -2.72 & $/(1)$ \\
\hline
\end{tabular}

TABLE 2: Results of cross-sectional dependence and unit root tests.

FDI, foreign direct investments.

\begin{tabular}{|c|c|c|c|c|c|c|c|c|}
\hline \multirow[t]{2}{*}{ Test } & \multicolumn{4}{|c|}{ Model with intercept } & \multicolumn{4}{|c|}{ Model with trend } \\
\hline & Value & $Z$ & $p$ & Robust $p$ & Value & $Z$ & $p$ & Robust $p$ \\
\hline$G t$ & -1.771 & 0.033 & 0.513 & 0.733 & -3.130 & -4.200 & 0.000 & 0.303 \\
\hline$G a$ & -5.288 & 1.524 & 0.936 & 0.797 & -11.200 & 0.534 & 0.703 & 0.310 \\
\hline Pt & -4.851 & 1.633 & 0.949 & 0.910 & -10.834 & -1.586 & 0.056 & 0.617 \\
\hline$P a$ & -3.423 & 0.814 & 0.792 & 0.800 & -9.979 & -0.763 & 0.223 & 0.570 \\
\hline
\end{tabular}

TABLE 3: Results panel cointegration test results.

Note: $\mathrm{Ga}$ and $\mathrm{Gt}$ test for the existence of cointegration in at least one of the cross-sectional units based on the null hypothesis of no cointegration. $\mathrm{Pt}$ and $\mathrm{Pa}$ test for cointegration for the whole panel based on the null hypothesis of no cointegration. 
positive and negative components in order to perform a further test for asymmetric cointegration between the variables. Descriptions of the decomposed variables are shown in Table 4. The test for hidden cointegration is conducted on the residuals of the negative and positive components of indigenous innovation and FDI, and results are reported in Table 5. First, the decomposed components are tested for $\mathrm{CD}$ using the Pesaran $\mathrm{CD}$ test, the results of which show a rejection of the null hypothesis of no CD. The presence of $\mathrm{CD}$ in the decomposed series means the CIPS Pesaran (2007) unit root test is appropriate for detecting asymmetric cointegration between the variables. The null for CIPS tests is that the series is I(1). The CIPS test assumes CD in the form of a single unobserved common factor. Only the model with trend has been reported here. The test was done using three lags, but only lag 1 is reported in this analysis. The test shows the stationarity of the decomposed at various levels. This evidence of stationarity means there exists longrun cointegration between the variables (Hatemi-J 2020). However, this cointegration is hidden because it is not visible in a linear fashion but in a non-linear manner. This result

TABLE 4: Description of decomposed variables.

\begin{tabular}{ll}
\hline Variable & Description \\
\hline$Y^{+}$ & Increases in indigenous innovation output \\
$Y^{-}$ & Decreases in indigenous innovation output \\
$\mathrm{X}^{+}$ & Increases in foreign direct investments \\
$\mathrm{X}^{-}$ & Decreases in foreign direct investments \\
$\Delta X$ & Change in indigenous innovation output \\
$\Delta Y$ & Change in foreign direct investments \\
\hline
\end{tabular}

TABLE 5: Results of asymmetric cointegration test.

\begin{tabular}{lcccc}
\hline Variable & $\begin{array}{c}\text { Cross-sectional } \\
\text { dependence test }\end{array}$ & Zt-bar & $p$ & Stationarity \\
\hline $\mathrm{Y}^{+}, \mathrm{X}^{+}$ & $50.69 *$ & -5.852 & 0.000 & $I(0)$ \\
$\mathrm{Y}^{-}, \mathrm{X}^{+}$ & $36.00^{*}$ & -7.396 & 0.000 & $I(0)$ \\
$\mathrm{Y}^{+}, \mathrm{X}$ & $46.24^{*}$ & -4.657 & 0.000 & $I(0)$ \\
$\mathrm{Y}^{-}, \mathrm{X}$ & $29.26^{*}$ & -2.859 & 0.002 & $I(0)$ \\
\hline
\end{tabular}

$*$, denotes a rejection of the null hypothesis at $1 \%$ significance level. indicates that estimating the relationship between the two variables in a linear form might mean missing some critical aspects of the relationship that are not obvious between the variables themselves, but which exist in their hidden components. The outcome of this analysis gives an indication that an estimation of the relationship can be done more effectively using a non-linear model.

\section{Model estimation}

After determining that cointegration exists in the positive and negative components of the variables, it is appropriate to estimate the relationship using the non-linear panel ARDL. The error correction term is estimated alongside this cointegration analysis. To achieve this, the PMG and the MG estimation method are used. These tools are particularly suited for this analysis because of their consistency in estimating long-run relationships in the context of dynamic panel data (Chudik \& Pesaran 2019; Pesaran \& Smith 1995). This can give effective results since the data come from different countries with potentially different characteristics and their reaction to FDI inflows. The estimation is based on the relationship between the decomposed components of the dependent variable (indigenous innovation) and the independent variable (FDI). This makes the relationship nonlinear since it is not estimated on the variables themselves but on their hidden properties. The study uses columns 1, 2, 3 and 4 which represent equations 9, 10, 11 and 12. The letters ' $a$ ' and ' $b$ ' represent PMG and MG estimates.

The analysis begins with a concentration on the nonlinearities between the variables for the entire sample. The results of this analysis are shown in Table 6. The Hausman test results show that the PMG is the efficient estimator for columns 1, 2 and 4, while the MG is suitable to estimate column 3. $X^{+}$and $X$ represent the positive and negative shock from FDI inflows, while $Y^{+}$and $Y^{-}$represent positive and negative shocks in indigenous innovation. The results of the first column show the error correction term and the speed at

TABLE 6: Results of non-linear auto-regressive distributed lag estimation.

\begin{tabular}{|c|c|c|c|c|c|c|c|c|c|c|c|c|c|c|c|c|}
\hline \multirow{4}{*}{$\begin{array}{l}\text { Independent } \\
\text { variables }\end{array}$} & \multicolumn{8}{|c|}{ Dependent variable: $\Delta \boldsymbol{Y}^{+}$} & \multicolumn{8}{|c|}{ Dependent variable: $\Delta \boldsymbol{Y}^{-}$} \\
\hline & \multicolumn{4}{|c|}{ (1) } & \multicolumn{4}{|c|}{ (2) } & \multicolumn{4}{|c|}{ (3) } & \multicolumn{4}{|c|}{ (4) } \\
\hline & \multicolumn{2}{|l|}{$1 a$} & \multicolumn{2}{|l|}{$1 \mathrm{~b}$} & \multicolumn{2}{|l|}{$2 a$} & \multicolumn{2}{|l|}{$2 b$} & \multicolumn{2}{|l|}{$3 a$} & \multicolumn{2}{|l|}{$3 \mathbf{b}$} & \multicolumn{2}{|l|}{$4 a$} & \multicolumn{2}{|l|}{$4 b$} \\
\hline & Coefficient & $t \mathrm{SE}$ & Coefficient & SE & Coefficient & SE & Coefficient & SE & Coefficient & SE & Coefficient & SE & Coefficient & SE & Coefficient & SE \\
\hline $\begin{array}{l}\text { Error } \\
\text { correction } \\
\text { term }\end{array}$ & $-0.551 * * *$ & 0.005 & $-0.525 * * *$ & 0.070 & $-0.465 * * *$ & 0.029 & $-0.462 * * *$ & 0.066 & $-0.250 * *$ & 0.011 & $-0.260 * * *$ & 0.057 & $-0.240 * *$ & 0.008 & $-0.247 * * *$ & 0.060 \\
\hline$\Delta X^{+}$ & $1.330 * *$ & 0.289 & $0.095 * *$ & 0.022 & - & - & - & - & - & - & - & - & 2.290 & 1.672 & $0.059 * *$ & 0.022 \\
\hline$\Delta x$ & - & - & - & - & 0.401 & 1.040 & 0.847 & 0.753 & -3.370 & 4.010 & 0.019 & 0.055 & - & - & - & - \\
\hline$\Delta X_{t-1}^{-}$ & - & - & - & - & -1.320 & 1.460 & -0.269 & 0.220 & 2.439 & 4.201 & $-0.042 * *$ & 0.014 & - & - & - & - \\
\hline$x^{+}$ & $1.235 *$ & 0.665 & $0.187 * *$ & 0.064 & - & - & - & - & - & - & - & - & $-3.300 * *$ & 1.340 & $-0.027 *$ & 0.009 \\
\hline$x$ & - & - & - & - & 3.79 & 4.027 & -0.603 & 0.376 & $-0.097 * *$ & 0.029 & $0.238 * *$ & 0.026 & - & - & - & - \\
\hline Constant & $2.966 * *$ & 0.009 & $2.718 * * *$ & 0.402 & $4.017 * *$ & 1.920 & $2.472 * * *$ & 0.397 & $2.209 * * *$ & 0.027 & $1.24 * *$ & 0.038 & $3.022 * *$ & 1.015 & $1.550 * *$ & 0.031 \\
\hline Log likelihood & 29024.651 & $1-$ & - & - & 11639.27 & - & - & - & 4554.247 & - & - & - & 39011.84 & - & - & - \\
\hline$p$-value & 0.760 & - & - & - & 0.706 & - & - & - & 0.000 & - & - & - & 0.621 & - & - & - \\
\hline
\end{tabular}


which the variables return to their long-term equilibrium after any shock. The error correction term shows statistically significant results across all equations, and the negative outcome confirms that long-run relationships exist and that there is long-term convergence after a shock in the system. Long-run equilibrium is achieved at a fast rate among all models, albeit varied. The error correction rate is faster from positive shocks at a rate of $52.5 \%$ return to equilibrium, while recovery from negative shocks is slowest at a rate of $24.7 \%$ where decreases in FDI also lead to a decrease in indigenous innovation output.

The causal analysis of the decomposed variables shows varied results among the positive and negative components of the variables. Considering the outcome from column 1, positive changes in FDI generally have a strong causal relationship with positive changes in indigenous innovation in the short term and in the long term. Negative changes in FDI inflows shown in column 2 have no causal effects on positive changes in indigenous innovation. However, the results of column 3 show that positive changes in FDI have a causal effect on negative changes in indigenous innovation in the long run. Furthermore, negative changes in FDI inflows demonstrated in column 4 do have a significant effect on negative changes in indigenous innovation in the short term. This indicates that reducing levels of FDI inflows will generally have an effect on reducing levels of indigenous innovation. Following the theoretical basis of the benefits of FDI inflows to host countries (Hymer 1976; Ohlin 1952), it is clear that foreign technological expertise that come with FDI are useful in fostering indigenous innovation in developing economies. This is obviously the reason why reducing levels of FDI has a long-term effect on decreasing levels of indigenous innovation in these developing economies. Multinational companies are known to be major benefactors of knowledge to local businesses (Zhao et al. 2019), hence increased numbers of multinationals in developing economies are major sources of knowledge that can boost indigenous innovation in countries where such expertise is not adequate.

Rankings by the Global Innovation Index (GII, 2019) shows that most developing countries are still lagging behind their developed counterparts in yearly improvement on innovation output. Cheung and Ping (2004) point out three benefits that come with FDI. Firstly, businesses of the receiving country adopt ideas from foreign counterparts and feed into their innovation efforts. Secondly, there is a spillover of knowledge as a result of people working with foreign firms and later working for domestic firms. Thirdly, foreign technologies in the domestic markets spur local firms to be more creative in bringing out new products. The integration of new knowledge learned from foreign firms with local knowledge can lead to successful indigenous innovation (Cassiman \& Veugelers 2002). The GII states that Hong Kong, Singapore and Luxembourg have had high performance in innovation due to some enabling factors including trade openness. The practice of opening up their economies to international trade has made these states the hubs of trade and investment in their respective regions. Learning-by-doing has become an important element in absorbing spillovers from foreign firms operating in the domestic market. The absorption of spillovers has a positive and significant effect on innovation output and performance, especially with firms that have the requisite expertise to absorb and use new technologies (Baark 2019).

Analysis of the asymmetries among the decomposed variables for individual regions is shown in Table 7. For countries from the Africa region, the results show that increasing amounts of FDI inflows are positively related to increased innovation among domestic enterprises in the long term. No relationship is obvious between decreases in FDI inflows and increases in innovation output, and there is no association between negative changes in FDI and negative changes in innovation output. However, increases in FDI inflows have a causal relationship with decreasing levels of innovation output. Evidence from selected countries in the Asia region reveal that increasing levels of FDI inflows lead to increases in indigenous innovation in both the long and short term. The dynamics for Asia are quite different, in that both positive and negative changes in FDI inflows have causal relations with negative changes in innovation output in the long term.

Furthermore, as with other regions, results of countries selected from the European region show that positive changes in FDI in the long term and in the short term have significant effects on the positive changes in indigenous innovation. However, countries on the continent can still increase innovation output in the face of long-term decreases in FDI as negative changes in FDI associate with positive changes in innovation output. Meanwhile, short term increases in FDI have a significant effect on decreases in indigenous innovation output. Results of countries selected from South America also show that positive changes in FDI generally have an effect on the positive changes in indigenous innovation in the countries selected from the region. Most importantly the effect of reducing levels of FDI on indigenous innovation is pronounced in this study. The effect of this in the short term is not significant; however, the long-term effect is significant, leading to a reduction in indigenous innovation among the countries in the region. These results show fairly similar results for all the regions. It is evident that increasing FDI inflows' influence increases indigenous innovation. On the flip side, reducing FDI generally is related to reducing innovation output in these countries. The exception is the European countries: in spite of reducing FDI inflows, innovation output still goes up.

\section{Panel causality tests}

Panel causality tests analyse the causal relationships between variables. In this section, following Hatemi-J (2011), after the variables have been decomposed into their positive and negative components, a linear causality test is done, then the non-linear causalities are also tested. The linear causality test results (in Table 8) show there exist linear causalities from 
TABLE 7: Results of non-linear auto-regressive distributed lag for individual regions.

\begin{tabular}{|c|c|c|c|c|c|c|c|c|}
\hline \multirow[t]{3}{*}{ Variables } & \multicolumn{8}{|c|}{ Region } \\
\hline & \multicolumn{2}{|c|}{ Africa } & \multicolumn{2}{|c|}{ Asia } & \multicolumn{2}{|c|}{ Europe } & \multicolumn{2}{|c|}{ South America } \\
\hline & Coefficient & Standard error & Coefficient & Standard error & Coefficient & Standard error & Coefficient & Standard error \\
\hline \multicolumn{9}{|l|}{ Dependent variable: $\Delta \boldsymbol{Y}^{+}$} \\
\hline$\Delta X_{t}^{+}$ & $-0.671 * *$ & 0.166 & $2.024 * *$ & 0.105 & $-0.226 * *$ & 0.015 & $0.114 * *$ & 0.025 \\
\hline$\Delta X_{t-1}^{+}$ & $0.015^{* *}$ & 0.010 & $1.027 * *$ & 0.084 & $-0.407^{* *}$ & 0.033 & $1.024 *$ & 0.050 \\
\hline$x^{+}$ & $1.037 * *$ & 0.010 & $0.726 * *$ & 0.019 & $-0.154 * *$ & 0.029 & $0.263 * *$ & 0.008 \\
\hline \multicolumn{9}{|l|}{ Dependent variable: $\Delta \boldsymbol{Y}^{+}$} \\
\hline$\Delta X_{t}^{-}$ & 0.014 & 0.219 & -0.114 & 0.180 & $-0.085 * *$ & 0.009 & 1.053 & 1.540 \\
\hline$\Delta X_{t-1}^{-}$ & 0.052 & 0.171 & -0.095 & 0.135 & 0.056 & 0.218 & 0.315 & 0.538 \\
\hline$x$ & -0.293 & 0.428 & 0.184 & 0.210 & $-0.106 * *$ & 0.018 & -0.462 & 0.601 \\
\hline \multicolumn{9}{|l|}{ Dependent variable: $\Delta \boldsymbol{r}$} \\
\hline$\Delta X_{t}^{+}$ & 0.083 & 0.175 & 0.049 & 0.049 & -0.051 & 0.141 & 0.194 & 0.125 \\
\hline$\Delta X_{t-1}^{+}$ & 0.191 & 0.228 & 0.003 & 0.081 & $-0.061 * *$ & 0.017 & 0.023 & 0.131 \\
\hline$x^{+}$ & 0.193 & 0.302 & $0.032 * *$ & 0.008 & 0.042 & 0.105 & 0.027 & 0.019 \\
\hline \multicolumn{9}{|l|}{ Dependent variable: $\Delta \boldsymbol{Y}$} \\
\hline$\Delta X_{t}^{-}$ & $0.256 * *$ & 0.084 & 0.101 & 0.078 & -0.009 & 0.107 & $-0.169 * *$ & 0.015 \\
\hline$\Delta X_{t-1}^{-}$ & $-0.110 * *$ & 0.062 & $-0.027^{* *}$ & 0.008 & $0.015 * *$ & 0.008 & 0.164 & 0.281 \\
\hline$x$ & $0.187 * *$ & 0.028 & $0.026 * *$ & 0.015 & $0.027^{* *}$ & 0.004 & $0.103 * *$ & 0.014 \\
\hline \multicolumn{9}{|l|}{ NARDL statistics } \\
\hline F-statistic & 3.67 & - & 2.82 & - & 3.82 & - & 6.92 & - \\
\hline Probability $F$ & 0.000 & - & 0.000 & - & 0.000 & - & 0.000 & - \\
\hline Adjusted $R^{2}$ & 0.21 & - & 0.17 & - & 0.31 & - & 0.34 & - \\
\hline Root mean square error & 0.183 & - & 0.222 & - & 0.258 & - & 0.292 & - \\
\hline
\end{tabular}

$* * *, * *$ and $*$, denote significance levels at $1 \%, 5 \%$ and $10 \%$.

TABLE 8: Panel causality test.

\begin{tabular}{lcccc}
\hline Null hypothesis & W-statistic & Z-bar & $\boldsymbol{p}$ & lag \\
\hline $\begin{array}{l}\text { Indigenous innovation does not } \\
\text { Granger-cause FDI }\end{array}$ & 3.056 & 5.148 & 3.007 & 1 \\
$\begin{array}{l}\text { FDI does not Granger-cause } \\
\text { Indigenous innovation }\end{array}$ & 2.357 & 3.304 & 0.001 & 1 \\
\hline
\end{tabular}

Source: Dumitrescu, E.-I. \& Hurlin, C., 2012, 'Testing for Granger non-causality in heterogeneous panels', Economic Modelling 29(4), 1450-1460. https://doi.org/10.1016/j. econmod.2012.02.014

$\mathrm{FDI}$, foreign direct investments.

TABLE 9: Asymmetric panel causality test between research and development and indigenous innovation.

\begin{tabular}{lccc}
\hline Null hypothesis & Wald Chi $^{2}$ & $p$ & Outcome \\
\hline $\mathrm{X}^{+}$does not cause $\mathrm{Y}^{+}$ & 70.158 & 0.000 & Reject \\
$\mathrm{X}^{-}$does not cause $\mathrm{Y}^{-}$ & 83.115 & 0.000 & Reject \\
$\mathrm{X}^{-}$does not cause $\mathrm{Y}^{+}$ & 1.227 & 0.541 & Accept \\
$\mathrm{X}^{+}$does not cause $\mathrm{Y}^{-}$ & 1.014 & 0.663 & Accept \\
$\mathrm{Y}^{+}$does not cause $\mathrm{X}^{+}$ & 3.981 & 0.173 & Accept \\
$\mathrm{Y}^{-}$does not cause $\mathrm{X}^{-}$ & 1.258 & 0.533 & Accept \\
$\mathrm{Y}^{-}$does not cause $\mathrm{X}^{+}$ & 0.870 & 0.714 & Accept \\
$\mathrm{Y}^{+}$does not cause $\mathrm{X}^{-}$ & 1.320 & 0.293 & Accept \\
\hline
\end{tabular}

FDI to indigenous innovation. The opposite causalities have proven not significant, hence there is no evidence of linear causality from indigenous innovation to FDI. In order to understand further the causal relationship between these variables, a non-linear panel causality test is conducted to investigate the asymmetric causal relations between the decomposed variables. In this study, the Hatemi-J test is employed to conduct a non-linear panel causality test between the decomposed components for the full sample. Results of this test are captured in Table 9. The results show that increasing FDI $\left(\mathrm{X}^{+}\right)$is a significant cause of increasing rates of indigenous innovation output $\left(\mathrm{Y}^{+}\right)$. The hypothesis that decreasing FDI ( $\left.\mathrm{X}^{-}\right)$does not Granger-cause decreases in innovation output $\left(Y^{-}\right)$has been rejected, indicating that when FDI inflows decrease, it causes a reduction in the rate at which indigenous innovations are churned out. However, decreasing FDI does not lead to increasing levels of innovation output, and increasing FDI equally does not lead to decreases in innovation output.

\section{Conclusion}

The main aim of this study is to analyse the asymmetric linkages between FDI and indigenous innovation. Following mixed findings on the relationship between the two variables using linear analysis, this study is conducted using the nonlinear panel ARDL to analyse the asymmetries between them. To achieve this, panel data of 20 developing countries from 1993 to 2017 taken from the World Development Indicators is employed. Within the non-linear ARDL model, the variables are decomposed into their negative and positive components in order to establish any long-run cointegration and asymmetric relationship among them. ACD test conducted on the variables resulted in a rejection of the null hypothesis of cross-sectional independence, hence the Pesaran (2007) CIPS was applied to test for stationarity. The Westerlund (2007) cointegration was used to test for linear cointegration, then the Hatemi-J (2020) asymmetric cointegration test was employed to test for hidden cointegration. Estimation of the asymmetric relationship between the variables was done using pooled MG and MG estimation methods. These estimation methods come with an error correction term which determines the speed of adjustment after a shock in the system. The study resulted in the following conclusions. 
First, the unit root test showed that the variables are stationary at first difference, but the results of the linear test for cointegration showed no cointegration between the variables. However, results of the asymmetric cointegration test showed there is long-run cointegration between the negative and positive components of the variables. This result is an indication that although the variables may not be cointegrated by themselves, there exists a long-run cointegration relationship between their hidden properties. Secondly, the error correction term tested in this relationship shows that the variables return to their long-term equilibrium after a shock resulting from increases or decreases in FDI inflows. The significance of the error correction term further affirms the existence of a long-run relationship among the variables analysed.

Thirdly, a test of the relationship between the decomposed components of the variables based on the non-linear panel ARDL shows that positive changes in FDI inflows generally result in positive changes in indigenous innovation output. The results effectively suggest that developing economies benefit from technologies and expertise brought into the domestic markets by foreign investors. Increasing FDI inflows leads to increasing levels of innovation output among indigenous firms in developing economies. Meanwhile, indigenous innovation takes a downward trend in the short term and in the long term when FDI inflows reduce. However, the selected countries from Europe show an upward trend in indigenous innovation output when FDI inflows reduce. This is an indication that such countries can still increase their levels of innovation even when FDI inflows decrease. An asymmetric causality test conducted on the decomposed variables shows strong causalities running from the positive and negative changes in FDI to the positive and negative changes in indigenous innovation.

Policy decisions regarding FDI inflows to developing countries should consider the non-linear relationships between FDI and indigenous innovation. Developing countries should pay more attention to the effect of reducing levels of FDI. While these countries can benefit from increasing FDI inflows, if there is not enough local capacity to absorb and use new technologies, then increasing and decreasing levels of FDI will stifle indigenous innovation. Trade policies should encourage multinational corporations from countries with advanced technologies to invest in and partner with local businesses in the domestic markets. Moreover, effective policy measures for developing countries to benefit from FDI inflows should be targeted at building the capacity of domestic firms to enable them to diffuse new technologies in the shortest possible time. This will ensure that variations in FDI will not drive down indigenous innovation.

The results of this study have brought interesting insights on this subject albeit focusing on developing countries. Hidden cointegration and asymmetries between these variables bring out salient issues that are critical for policy decisions and further research. Future studies may analyse the asymmetric relationship between FDI and indigenous innovation in developed countries and developing countries in other regions.

\section{Acknowledgements}

We are grateful to the institutions that provided funding for this work, and also to the editorial team and reviewers for their various roles in making this work a success.

\section{Competing interests}

The authors have declared that no competing interest exists.

\section{Author's contributions}

All authors contributed equally to this work.

\section{Funding information}

This work is supported by National Natural Science Foundation of China, and the Social Science Funding Project of Jiangsu Province.

\section{Data availability statement}

Data is taken from the World Development Indicators of the World Bank group: https:/ /www.data.worldbank.org/ indicator

\section{Disclaimer}

The views and opinions expressed in this article are those of the authors and do not necessarily reflect the official policy or position of any affiliated agency of the authors.

\section{References}

Acemoglu, D., 2002, 'Directed technical change', The Review of Economic Studies 69(4), 781-809. https://doi.org/10.1111/1467-937X.00226

Aitken, B.J. \& Harrison, A.E., 1999, 'Do domestic firms benefit from direct foreign investment? Evidence from Venezuela', American Economic Review 89(3), 605-618. https://doi.org/10.1257/aer.89.3.605

Araç, A. \& Hasanov, M., 2014, 'Asymmetries in the dynamic interrelationship between energy consumption and economic growth: Evidence from Turkey', Energy Economics 44, 259-269. https://doi.org/10.1016/j.eneco.2014.04.013

Awate, S., Larsen, M.M. \& Mudambi, R., 2015, 'Accessing vs sourcing knowledge: A comparative study of R\&D internationalization between emerging and advanced economy firms', Journal of International Business Studies 46(1), 63-86. https:// doi.org/10.1057/jibs.2014.46

Baark, E., 2019, 'China's indigenous innovation policies', East Asian Policy 11(02), 5-12. https://doi.org/10.1142/S1793930519000126

Barasa, L., Vermeulen, P., Knoben, J., Kinyanjui, B. \& Kimuyu, P., 2019, 'Innovation inputs and efficiency: Manufacturing firms in Sub-Saharan Africa', European Journal of Innovation Management 22(1), 59-83. https://doi.org/10.1108/EJIM11-2017-0176

Bayramoglu, A.T. \& Yildirim, E., 2017, 'The relationship between energy consumption and economic growth in the USA: A non-linear ARDL bounds test approach', Energy and Power Engineering 9(03), 170. https://doi.org/10.4236/epe.2017.93013

Block, J.H., De Vries, G., Schumann, J.H. \& Sandner, P., 2014, 'Trademarks and venture capital valuation', Journal of Business Venturing 29(4), 525-542. https://doi. org/10.1016/j.jbusvent.2013.07.006

Bloom, N., Draca, M. \& Van Reenen, J., 2016, 'Trade induced technical change? The impact of Chinese imports on innovation, IT and productivity', Review of Economic Studies 83(1), 87-117. https://doi.org/10.1093/restud/rdv039

Burhan, M., Singh, A.K. \& Jain, S.K., 2017, 'Patents as proxy for measuring innovations: A case of changing patent filing behavior in Indian public funded research A case of changing patent filing behavior in Indian public funded research organizations', Technological Forecasting and
https://doi.org/10.1016/j.techfore.2016.04.002 
Burke, M., Hsiang, S.M. \& Miguel, E., 2015, 'Global non-linear effect of temperature on economic production', Nature 527(7577), 235. https://doi.org/10.1038/ nature15725

Cassiman, B. \& Veugelers, R., 2002, 'Complementarity in the innovation strategy: Internal R\&D, external technology acquisition and cooperation in R\&D', IESE Business School Working Paper No. 457, University of Navarra, Pamplona.

Caves, R.E., 1974, 'Causes of direct investment: Foreign firms' shares in Canadian and United Kingdom manufacturing industries', Review of Economics and Statistics 56(3), 279-293. https://doi.org/10.2307/1923965

Cheung, K. \& Ping, L., 2004, 'Spillover effects of FDI on innovation in China: Evidence from the provincial data', China Economic Review 15(1), 25-44. https://do org/10.1016/S1043-951X(03)00027-0

Chudik, A. \& Pesaran, M.H., 2019, 'Mean group estimation in presence of weakly cross-correlated estimators', Economics Letters 175(C), 101-105.

Clancy, M.S., Heisey, P., Ji, Y. \& Moschini, G., 2020, The roots of agricultural innovation Patent evidence of knowledge spillovers, National Bureau of Economic Research, Cambridge, MA.

Cornell University, INSEAD \& WIPO 2019, The Global Innovation Index 2019: Creating healthy lives - The future of medical innovation, Cornell University, Ithaca, NY.

Crosby, M., 2000, 'Patents, innovation and growth', Economic Record 76(234), 255-262. https://doi.org/10.1111/j.1475-4932.2000.tb00021.x

Dumitrescu, E.-I. \& Hurlin, C., 2012, 'Testing for Granger non-causality in heterogeneous panels', Economic Modelling 29(4), 1450-1460. https://doi. org/10.1016/j.econmod.2012.02.014

Fernandes, A.M. \& Paunov, C., 2013, 'Does trade stimulate product quality upgrading?', Canadian Journal of Economics/Revue Canadienne d'économique 46(4), 1232-1264. https://doi.org/10.1111/caje.12047

Fu, X. \& Gong, Y., 2011, 'Indigenous and foreign innovation efforts and drivers of technological upgrading: Evidence from China', World Development 39(7), 1213-1225. https://doi.org/10.1016/j.worlddev.2010.05.010

Fu, X., Pietrobelli, C. \& Soete, L., 2011, 'The role of foreign technology and indigenous innovation in the emerging economies: Technological change and catching-up', World Development 39(7), 1204-1212. https://doi.org/10.1016/j.worlddev.2010.05.009

Gotsch, M. \& Hipp, C., 2012, 'Measurement of innovation activities in the knowledgeintensive services industry: A trademark approach', The Service Industries Journa 32(13), 2167-2184. https://doi.org/10.1080/02642069.2011.574275

Hatemi-J, A., 2011, 'Asymmetric panel causality tests with an application to the impact of fiscal policy on economic performance in Scandinavia', MPRA Paper No. 55527, University Library of Munich, Munich.

Hatemi-J, A., 2014, 'Asymmetric generalized impulse responses with an application in finance', Economic Modelling 36, 18-22. https://doi.org/10.1016/j.econmod. 2013.09.014

Hatemi-J, A., 2020, 'Hidden panel cointegration', Journal of King Saud UniversityScience 32(1), 507-510

Howell, A., 2019, 'Industry relatedness, FDI liberalization and the indigenous innovation process in China', Regional Studies 54(2), 229-243. https://doi. org/10.2139/ssrn.3553376

Hu, A.G.Z. \& Jefferson, G.H., 2002, 'FDI impact and spillover: Evidence from China's electronic and textile industries', World Economy 25(8), 1063-1076. https://doi. electronic and textile industries,
org/10.1111/1467-9701.00481

Hymer, S.H., 1976, The international operations of national firms: A study of foreign direct investment, MIT Press, Cambridge, MA.

lacovone, L., 2012, 'The better you are the stronger it makes you : Evidence on the asymmetric impact of liberalization', Journal of Development Economics 99(2), 474-485. https://doi.org/10.1016/j.jdeveco.2012.06.001

Iacovone, L., Keller, W. \& Rauch, F., 2011, Innovation responses to import competition, Mimeo, Princeton University, Princeton, NJ.

Intarakumnerd, P. \& Goto, A., 2018, 'Role of public research institutes in national innovation systems in industrialized countries: The cases of Fraunhofer, NIST, CSIRO, AIST, and ITRI', Research Policy 47(7), 1309-1320. https://doi.org/10.1016/ j.respol.2018.04.011

Kastrati, S.K., Ramadani, V., Dana, L.P. \& Ratten, V., 2016, 'Do foreign direct investments accelerate economic growth? The case of the Republic of Macedonia', International Journal of Competitiveness 1(1), 71. https://doi.org/10.1504/ijc.2016.075903

Kouton, J., 2019, 'The asymmetric linkage between energy use and economic growth in selected African countries: Evidence from a nonlinear panel autoregressive distributed lag model', Energy Economics 83, 475-490. https://doi.org/10.1016/j. distributed lag model',

Kumari, R. \& Sharma, A.K., 2017, 'Determinants of foreign direct investment in developing countries: A panel data study', International Journal of Emerging Markets 12(4), 658-682. https://doi.org/10.1108/IJoEM-10-2014-0169

Li, C., Pervaiz, K., Asif Khan, M., Ur Rehman, F. \& Oláh, J., 2019, 'On the asymmetries of sovereign credit rating announcements and financial market development in the European region', Sustainability 11(23), 6636. https://doi.org/10.3390/su11236636

Lin, J.-B., Liang, C.-C. \& Tsai, W., 2019, 'Nonlinear relationships between oil prices and implied volatilities: Providing more valuable information', Sustainability 11(14), 3906. https://doi.org/10.3390/su11143906
Lv, X., Qi, Y. \& Dong, W., 2020, 'Dynamics of environmental policy and firm innovation: Asymmetric effects in Canada's oil and gas industries', Science of The Total Environment 712, 136371. https://doi.org/10.1016/j.scitotenv.2019.136371

Maurer, M.R., 2017, 'Supply chain trade and technological transfer in the ASEAN+ 3 region', China Economic Review 46, 277-289. https://doi.org/10.1016/j.chieco.2017.02.001

Medina, P., 2017, Import competition, quality upgrading and exporting: Evidence from the Peruvian apparel industry, University of Toronto Mimeo, Toronto.

Moosa, I., 2002, Foreign direct investment: Theory, evidence and practice, Palgrave Macmillan, London.

Nazlioglu, S., 2011, 'World oil and agricultural commodity prices: Evidence from nonlinear causality', Energy Policy 39(5), 2935-2943. https://doi.org/10.1016/j. enpol.2011.03.001

Ndoricimpa, A., 2017, 'Analysis of asymmetries in the nexus among energy use pollution emissions and real output in South Africa', Energy 125, 543-551. https:// doi.org/10.1016/j.energy.2017.02.065

Nollet, J., Filis, G. \& Mitrokostas, E., 2016, 'Corporate social responsibility and financial performance: A non-linear and disaggregated approach', Economic Modelling 52(Part B), 400-407. https://doi.org/10.1016/j.econmod.2015.09.019

OECD, 2002, Foreign direct investment for development: Maximising benefits, minimising costs, Organisation for Economic Co-operation and Development, Paris.

Ohlin, B., 1952, Interregional and international trade, vol. 39, Harvard University Press, Cambridge, MA.

Pesaran, M.H., 2007, 'A simple panel unit root test in the presence of cross-section dependence', Journal of Applied Econometrics 22(2), 265-312. https://doi. org/10.1002/jae.951

Pesaran, M.H. \& Smith, R., 1995, 'Estimating long-run relationships from dynamic heterogeneous panels', Journal of Econometrics 68(1), 79-113. https://doi. org/10.1016/0304-4076(94)01644-F

Qin, X. \& Du, D., 2017, 'Do external or internal technology spillovers have a stronger influence on innovation efficiency in China?', Sustainability 9(9), 1574. https://doi. org/10.3390/su9091574

Razin, A. \& Sadka, E., 2012, Foreign direct investment: Analysis of aggregate flows, Princeton University Press, Princeton, NJ.

Rodrigues, M.G. \& Da Costa, F.J.P., 2018, Technology and competitiveness: Technological innovation for developing economies growth, International Journa of Advances in Management and Economics 4(4), 57-65.

Salisu, A.A. \& Isah, K.O., 2017, 'Revisiting the oil price and stock market nexus: A nonlinear panel ARDL approach', Economic Modelling 66, 258-271. https://doi. org/10.1016/j.econmod.2017.07.010

Schautschick, P. \& Greenhalgh, C., 2016, 'Empirical studies of trade marks-the existing economic literature', Economics of Innovation and New Technology 25(4), 358-390. https://doi.org/10.1080/10438599.2015.1064598

Seenaiah, K. \& Rath, B.N., 2018, 'Determinants of innovation in selected manufacturing firms in India: Role of R\&D and exports', Science, Technology and Society 23(1), firms in India: Role of R\&D and exports', Science, Te
65-84. https://doi.org/10.1177/0971721817744445

Shamsub, H., 2014, 'Interrelationships between inward FDI and indigenous innovation in developing economies', Global Business and Economics Review 16(3), 296-309. $\mathrm{https}$ ://doi.org/10.1504/GBER.2014.063074

Shin, Y., Yu, B. \& Greenwood-Nimmo, M., 2014, 'Modelling asymmetric cointegration and dynamic multipliers in a nonlinear ARDL framework', in W. Horrace \& R. Sickles (Eds.), Festschrift in honor of Peter Schmidt: Econometric methods and applications, Springer, New York, pp. 281-314.

Shu, P. \& Steinwender, C., 2019, 'The impact of trade liberalization on firm productivity and innovation', Innovation Policy and the Economy 19(1), 39-68. https://doi. org/10.1086/699932

Tan, H. \& Mathews, J.A., 2015, 'Accelerated internationalization and resource leverage strategizing: The case of 'Chinese wind turbine manufacturers', Journal of World Business 50(3), 417-427. https://doi.org/10.1016/j.jwb.2014.05.005

Tian, X., 2007, 'Accounting for sources of FDI technology spillovers: Evidence from China', Journal of International Business Studies 38(1), 147-159. https://doi. org/10.1057/palgrave.jibs.8400245

UNCTAD, 2007, World investment report, United Nations Conference on Trade and Development, Geneva.

Westerlund, J., 2007, 'Testing for error correction in panel data', Oxford Bulletin of Economics and Statistics 69(6), 709-748. https://doi.org/10.1111/j.1468-0084.2007.00477.x

Xie, Z. \& Li, J., 2018, 'Exporting and innovating among emerging market firms: The moderating role of institutional development', Journal of International Business Studies 49(2), 222-245. https://doi.org/10.1057/s41267-017-0118-4

Yoshioka-Kobayashi, T., Miyanoshita, T. \& Kanama, D., 2020, 'Revisiting incremental product innovations in the food-manufacturing industry: An empirical study on the effect of intellectual property rights', Journal of Economic Structures 9, 1-19. https://doi.org/10.1186/s40008-020-00213-5

Zhao, H., Ozer, M., Rong, W. \& Mondejar, R., 2019, 'Do management innovations of indigenous firms benefit from managerial spillovers from multinational enterprises?', Management International Review 59(2019), 919-947. https://doi. org/10.1007/s11575-019-00403-9 